\title{
KERAGAMAN BAHAN MAKANAN UNTUK SARAPAN ANAK SEKOLAH DI INDONESIA
}

\section{Food Diversification for the Breakfast of Indonesian School children}

\author{
Dewi Permaesih, Yuniar Rosmalina \\ Pusat Penelitian dan Pengembangan Upaya Kesehatan Masyarakat \\ Badan Penelitian dan Pengembangan Kesehatan, Kementerian Kesehatan R.I \\ JI. Percetakan Negara No. 29 Jakarta Pusat \\ E-mail: dpermaesih2002@yahoo.com
}

\begin{abstract}
Breakfast (5-9 AM) is contributed around one third of daily nutrient intake. Some studies shown that breakfast can maintain the blood glucose level, increase school performance and prevent obesity. This study aimed to determine the food variety of breakfast consumed by most Indonesian people, aged 6-18 years. Analysis was conducted using secondary data taken from the Individual Food Consumption Survey (SKMI) 2014. The study was cross-sectional survey design conducted in 33 provinces in Indonesia in MayJune 2014. $27870(77.5 \%)$ subjects were met the criteria. The age group of 6-12 years old consists of 7739 males and 7069 females, while aged 13-18 years old consists of 6612 males and 6450 females. Almost 60 percent $(59,1 \%)$ subjects consumed a combination of 3 food groups. 72,3 percent were consumed one food which was consist only serealia. Subjects who consumed with combination of 2 food groups such as serealia and water $(49.6 \%)$, serealia and animal food $(18.2 \%)$. Subjects who consumed combination of 3 food groups, such as serealia, animal food, and fat, were 49.6 percent. In conclusion, most students aged 6-18 years had breakfast but the variety of food was not adequate yet.
\end{abstract}

Keywords: breakfast, food diversity, school children

\section{ABSTRAK}

Sarapan atau makan pagi (jam 5-9 pagi) penting untuk konsumsi makanan sehari. Sarapan dapat membantu mempertahan kadar gula darah, meningkatkan konsentrasi belajar serta mencegah terjadinya kegemukan. Perlu diperhatikan selain jumlah makanan juga keragaman jenis yang dikonsumsi. Tujuan analisis adalah mendapatkan informasi tentang keragaman bahan makanan yang biasa dikonsumsi penduduk di Indonesia, umur 6-18 tahun. Dilakukan analisis data hasil Survei Konsumsi Makanan Individu (SKMI) 2014 dari rumah-tangga terpilih di 33 provinsi di Indonesia pada bulan Mei-Juni 2014 dengan desain penelitian potong-lintang. Sampel terdiri dari umur 6-12 tahun usia sekolah dasar (7739 orang lakilaki dan 7069 perempuan) dan umur 13-18 tahun usia sekolah menengah (6612 laki-laki dan 6450 perempuan). Hasil analisis menunjukkan, sebanyak 77,5 persen (27870 individu) sampel melakukan sarapan. Sebanyak 59,1 persen responden mengonsumsi 3 kelompok bahan makanan. Responden yang mengonsumsi satu kelompok bahan makanan saja, seperti serealia, sejumlah 72,3 persen, sedangkan dari yang mengonsumsi dua kelompok makanan, sebanyak 49,6 persen mengonsumsi serealia dan air putih serta 18,2 persen mengonsumsi kombinasi kelompok serealia dan kelompok hewani. Responden mengonsumsi tiga kelompok bahan makanan, paling banyak mengonsumsi kombinasi kelompok serealia, hewani dan minyak $(49,6 \%)$, diikuti kombinasi kelompok serealia, kelompok sayur dan minyak. Dapat disimpulkan, sebagian besar anak sekolah usia 6-18 tahun sarapan namun keragamannya masih kurang.

Kata kunci: sarapan, keragaman bahan makanan, anak sekolah 


\section{PENDAHULUAN}

$\mathrm{M}$ embiasakan makan makanan beraneka ragam adalah prinsip pertama dari Gizi Seimbang, karena tak ada satu pun makanan yang mengandung seluruh zat gizi yang dibutuhkan tubuh, kecuali ASI (air susu ibu) untuk bayi sampai umur 6 bulan. Keragaman konsumsi makanan akan saling memenuhi kebutuhan zat gizi. Ketersediaan makanan di rumah-tangga berperan dalam mempengaruhi pemilihan makanan yang akan dikonsumsi anggota rumah-tangga pada saat waktu makan. Waktu untuk menyiapkan sarapan (makan pagi) umumnya singkat sehingga ibu biasanya menyiapkan makanan yang praktis, mudah dan cepat untuk disajikan.

Sarapan adalah makanan dan minuman yang dikonsumsi sebelum melakukan aktivitas. Penanaman pembiasaan sarapan berguna untuk menunjang energi demi optimalnya aktivitas belajar anak di sekolah dan aktivitas lainnya. Sarapan dengan makanan yang beraneka ragam menjamin kecukupan sumber zat gizi untuk tenaga, zat pembangun dan zat pengatur.

Banyak yang tidak menyadari pentingnya sarapan. Sarapan (jam 5-9 pagi) penting untuk konsumsi makanan sehari. Sarapan dapat membantu mempertahan kadar gula darah, meningkatkan konsentrasi belajar serta mencegah terjadinya kegemukan. ${ }^{1,2,3,4}$ Batasan waktu untuk sarapan tidaklah sama. Menurut Hardinsyah \& Aries (2012), ${ }^{5}$ kondisi Indonesia sebanding dengan di Amerika Latin, bahwa sarapan diartikan kegiatan makan dan minum dari jam 05:00 hingga jam 09:00 pagi; bila lewat interval waktu itu tidak bisa dikatakan sarapan.

Sementara menurut Wilson et al di New Zealand ${ }^{6}$ dan Smith et al di Australia (2010), ${ }^{7}$ waktu makan pagi adalah antara jam 6 dan 9 pagi. Batasan waktu sarapan yang akhirnya digunakan adalah batasan yang diajukan oleh Hardinsyah \& Aries $(2012)^{5}$, yakni makanan yang dikonsumsi di pagi hari sebelum beraktivitas dari jam 5 hingga jam 9 .

Anak usia sekolah perlu energi yang cukup untuk pertumbuhan dan melakukan aktivitas fisik sehari-hari. Sarapan merupakan bagian penting dari konsumsi makanan sehari, karena menyediakan energi dan zat gizi lainnya untuk peningkatan konsentrasi belajar serta sumber energi dan untuk aktivitas fisik. Penelitian juga menunjukkan sarapan dapat membantu dalam mempertahankan berat badan. Orang yang tidak sarapan cenderung mengonsumsi camilan yang umumnya tinggi lemak dan gula, tetapi rendah vitamin, mineral dan seratnya. Hasil penelitian Sukati $(1991)^{8}$ menunjukkan, kebiasaan tidak makan pagi dan keadaan anemia berpengaruh nyata pada konsentrasi belajar. Hasil penelitian Permaesih $(2005)^{9}$ menunjukkan, kebiasan sarapan merupakan salah satu faktor risiko terjadinya anemia. Sementara hasil Riskesdas $2010^{10}$ menunjukkan, sebanyak 44 persen anak sarapan dengan gizi kurang.

Anak usia sekolah dasar (6-12 tahun) dan sekolah menengah, baik pertama maupun atas (13-18 tahun), banyak melakukan aktivitas fisik. Oleh karena itu, pada masa ini anak membutuhkan energi untuk pertumbuhan dan penunjang aktivitasnya. Energi dalam tubuh dapat timbul karena adanya pembakaran karbohidrat, protein dan lemak. Agar energi tercukupi, konsumsi makanan perlu memiliki nilai gizi yang tinggi. Semua anak usia sekolah dasar dan sekolah menengah; yang menjadi responden dalam Survei Konsumsi Makanan Individu (SKMI) menjadi sampel pada analisis data ini.

SKMI mengumpulkan informasi berbagai jenis bahan makanan yang dikonsumsi penduduk Indonesia, termasuk anak usia sekolah. ${ }^{11}$ Dari hasil SKMI ingin diketahui bagaimana keragaman makanan untuk setiap sumber zat gizi, bahan makanan apa saja yang biasa dikonsumsi saat sarapan. Keragaman konsumsi makanan yang dimaksud adalah keragaman dari kelompok makanan yang dikonsumsi pada satu waktu makan utamanya saat makan pagi, bukan keragaman dari konsumsi makanan dalam kelompok makanan. Informasi mengenai keragamanan makanan yang dikonsumsi saat sarapan oleh anak sekolah merupakan hal penting untuk memberi masukan/saran dalam meningkatkan produktivitas anak sekolah. Artikel ini bertujuan untuk mendapatkan informasi keragaman bahan makanan dari sarapan yang dikonsumsi anak sekolah.

\section{METODE PENELITIAN}

Artikel ini merupakan analisis lanjut dari data Riskesnas, yaitu SKMI 2014 dan 
Riskesdas 2013, dengan desain potong-lintang. Analisis dilakukan di Pusat Teknologi Terapan Kesehatan dan Epidemiologi Klinik (TTK-EK) Bogor dari bulan Juni-Oktober 2015. Populasi adalah seluruh rumah-tangga di 33 provinsi yang menjadi sampel SKMI 2014. Sampel adalah semua anak usia sekolah dari responden SKMI 2014 yang memiliki data konsumsi makanan dan minuman.

Kriteria inklusi adalah semua responden berumur 6 hingga 18 tahun yang mempunyai data konsumsi dalam SKMI 2014 dan data sosial ekonomi dalam Riskesdas 2013. Sementara kriteria ekslusinya adalah semua responden yang tidak memenuhi kriteria inklusi.

Instrumen yang digunakan adalah kuesioner rumah-tangga dan kuesioner individu SKMI 2014 dan laporan Riskesdas 2013. Data yang sudah dikumpulkan saat pelaksanaan SKMI 2014 dan Riskesdas 2013 dipilih sesuai dengan variabel yang diperlukan untuk analisis lanjut ini.

Data yang digunakan dalam analisis ini adalah data entry konsumsi makanan dari SDT $2014^{11}$ dan data lain dari Riskesdas 2013,12 yang terdiri dari identitas subyek, usia, jenis kelamin, wilayah tempat tinggal, status ekonomi rumah-tangga, tingkat pendidikan, jenis dan jumlah bahan makanan serta waktu makan.

Pengolahan dan analisis data dilakukan dengan memverifikasi, apakah semua variabel yang diperlukan telah tersedia datanya, terutama variabel waktu makan. Proses cleaning data dilakukan untuk memastikan bahwa data yang digunakan logis dan sesuai. Subyek dikeluarkan bila data waktu konsumsi makanan tidak sesuai dengan kriteria inklusi. Selain itu juga dikeluarkan bila subyek sedang hamil.

Dalam proses analisis data, umur sampel dibagi menjadi 2 kelompok umur, yakni usia sekolah dasar 6-12 tahun dan usia sekolah menengah 13-18 tahun. Untuk tempat tinggal tidak dilakukan perubahan, mengikuti data yang tersedia, yakni perkotaan dan perdesaan. Untuk mengetahui tingkat ekonomi responden, dilakukan pengelompokan pada variabel kuintil kepemilikan: kuintil bawah, menengah bawah dan menengah menjadi kelompok kemampuan ekonomi kurang, sedangkan kuintil kepemilikan menengah atas dan teratas menjadi kelompok kemampuan ekonomi mampu. Tingkat pendidikan dibagi menjadi kelompok yang tidak/belum sekolah dan sudah sekolah.

Untuk mengkaji keragaman makanan yang dikonsumsi, dibuat pengelompokan bahan makanan yang baru menjadi 7 kelompok sebagai berikut: (1) Sumber karbohidrat, yang menjadi sumber energi/tenaga, terdiri dari kelompok serealia dan olahannya, umbi batang berpati dan olahannya, serta gula, sirup dan konfeksioneri; (2) Sumber protein hewani, yang berfungsi sebagai sumber zat pembangun, terdiri dari daging dan olahannya, jeroan, nondaging dan olahannya, ikan hewan laut dan olahannya, telur dan olahannya, susu dan olahannya serta makanan komposit; (3) Sumber protein nabati, yang menjadi sumber zat pembangun lainnya, berasal dari kacangkacangan, biji-bijian, polong-polongan dan olahannya; (4) Kelompok sayur dan olahan sebagai sumber zat pengatur; (5) Kelompok buah dan olahan, yang bersama dengan sayur merupakan sumber zat pengatur karena mengandung berbagai vitamin dan mineral; (6) Kelompok minyak dan lemak, selain sebagai penyedap, juga sebagai sumber zat tenaga; (7) Kelompok air. Kelompok bahan makanan bumbu dan olahan serta kelompok suplemen dan jamu/herbal tidak dimasukkan ke dalam perhitungan keragaman.

Penentuan jenis bahan makanan sarapan yang banyak dikonsumsi didasarkan pada tiga peringkat pertama jenis bahan makanan yang dikonsumsi subyek. Keragaman bahan makanan ditentukan berdasarkan konsumsi dari 7 jenis jenis bahan yang telah dikelompokkan. Bila mengonsumsi $\geq 4$ kelompok bahan makanan dianggap sudah baik.

Analisis lanjut ini tidak membutuhkan persetujuan etik karena tidak melibatkan sampel manusia/hewan secara langsung. Namun, pada saat SKMI persetujuan etik sudah didapatkan dari Komisi Etik Badan Litbang Kesehatan.

\section{HASIL}

\section{Gambaran Responden}

Subyek yang dianalisis adalah seluruh responden SKMI 2014 yang berumur 6-18 tahun, tidak sedang hamil dan mengonsumsi sarapan pagi antara jam 5 dan jam 9 pagi. Tersebar di 33 provinsi seluruh Indonesia. Dari sebanyak 35950 individu pada kelompok umur 
6-18 tahun, yang memenuhi kriteria inklusi sebanyak 27870 individu (77,5\%). Rerata umur seluruh responden 12,8 tahun.

Dalam pengolahan data, kelompok umur dibagi menjadi 2 kelompok, yakni kelompok umur 6-12 tahun usia sekolah dasar dan kelompok umur 13-18 tahun usia sekolah menengah (Tabel 1). Responden dengan jenis kelamin laki-laki persentasenya lebih tinggi pada kelompok umur 6-12 tahun (52,3\%) dibandingkan dengan kelompok 13-18 tahun $(50,6 \%)$, sedangkan jenis kelamin perempuan persentasenya lebih tinggi pada kelompok umur 13-18 tahun (49,4\%) dibandingkan dengan kelompok umur 6-12 tahun (47,7\%). Persentase responden yang tinggal di perkotaan hampir sama antara umur 6-12 tahun (44,1\%) dan umur 13-18 tahun (44,0\%). Begitu juga responden yang tinggal di perdesaan, persentasenya hampir sama, yaitu kelompok usia 6-12 tahun sebanyak 55,9 persen dan kelompok usia 13-18 tahun sebanyak 56,0 persen. Sebaran responden yang kurang mampu, persentasenya lebih tinggi pada umur 13-16 tahun $(59,6 \%)$ dibandingkan dengan umur 6-12 tahun $(57,7 \%)$, sedangkan responden dengan kategori mampu, persentasenya lebih tinggi pada kelompok umur 6-12 tahun (42,3\%) dibandingkan dengan kelompok umur 13-18 tahun (40,4\%).

Dilihat dari pendidikan, masih ada 20,4 persen responden yang tidak sekolah, yaitu 17,9 persen pada kelompok umur 6-12 tahun dan 2,5 persen pada kelompok umur 13-18 tahun.

Setiap wilayah mempunyai kebiasaan atau tradisi yang berbeda dalam kegiatan makan. Dari sebanyak 35950 responden tiap provinsi, pada kelompok yang masuk dalam kriteria inklusi, sebanyak 77,5 persen melakukan sarapan. Distribusi jumlah responden yang melakukan sarapan berdasarkan provinsi disajikan pada Tabel 2 .

Tabel 2 memperlihatkan, ada 8 provinsi yang penduduknya lebih dari 80 persen melakukan sarapan. Provinsi dengan jumlah penduduk terbanyak melakukan sarapan adalah provinsi Kalimantan Tengah (83,7\%), Nusa Tenggara Barat $(83,6 \%)$, Jawa Barat $(81,4 \%)$, Banten (81,4\%), DKI Jakarta $(81,4 \%)$, Kalimantan Selatan (80,9\%), Aceh $(80,5 \%)$, dan Bali $(80,4 \%)$.

\section{Keragaman Konsumsi Makanan}

Analisis yang telah dilakukan menunjukkan, makin banyak keragamanan bahan makanan yang dikonsumsi, semakin sedikit jumlah responden. Tabel 3 menunjukkan, jumlah yang paling banyak adalah keragaman konsumsi 3 sebanyak 27,3 persen dan keragaman konsumsi 4 sebanyak 27,1 persen.

Hasil analisis menunjukkan, sekitar 60 persen responden mengonsumsi makanan sarapan kurang dari 4 jenis kelompok bahan makanan. Rerata seluruh responden umumnya mengonsumsi sarapan terdiri dari 3 jenis bahan makanan, dan hampir seluruh responden mengonsumsi serealia.

Kombinasi dari ke-7 kelompok bahan makanan tersebut berbeda-beda. Jumlah responden yang mengonsumsi 1-3 keragaman dan yang banyak dikonsumsi disajikan pada Tabel 4.

Tabel 4 menunjukkan, pada responden yang mengonsumsi keragaman 1 jenis sebanyak 14 persen dari seluruh responden. Jenis kelompok bahan makanan yang dikonsumsi adalah serealia (72\%), terutama beras putih.

Sebanyak 20 persen responden lainnya adalah kelompok yang mengonsumsi 2 jenis makanan kombinasi. Sebanyak 49,6 persen pada kelompok ini mengonsumsi dengan kombinasi kelompok serealia dan air putih, diikuti kombinasi kelompok serealia dan kelompok hewani $(18,2 \%)$, sisanya kombinasi kelompok serealia dan kelompok berbeda lainnya.

Selanjutnya 27 persen dari seluruh responden adalah kelompok yang mengonsumsi 3 kelompok bahan makanan. Kombinasi yang paling banyak adalah kombinasi kelompok serealia, kelompok hewani dan minyak (49,6\%), diikuti kombinasi kelompok serealia, kelompok sayur dan minyak (14,9\%), kemudian kombinasi kelompok serealia, kelompok nabati dan air (10,9\%), sisanya kombinasi kelompok serealia dan kelompok bahan makanan yang berbeda-beda.

Hasil analisis berdasarkan 2 kelompok keragaman, yakni keragaman 1-3 dan keragaman 4-7, dapat dilihat pada Tabel 5 . Hasil analisis menunjukkan, ada hubungan antara umur responden dan keragaman bahan makanan. Tabel 5 selanjutnya menunjukkan, keragaman konsumsi makanan sarapan pada 
kelompok umur 6-12 tahun lebih dari 54 persen keragaman makanannya 1-3 jenis, sedangkan pada kelompok umur 13-18 tahun sebanyak 51,2 persen. Hasil analisis menunjukkan, ada hubungan secara bermakna $(<0,05)$ antara umur dengan keragaman konsumsi makanan sarapan.

Berdasarkan kelompok umur, sebanyak 54,5 persen anak kelompok umur 6-12 tahun dan 45,5 persen anak kelompok umur 13-18 tahun keragamanan bahan makanannya pada 1-3 jenis kelompok bahan makanan dari jenis dan yang paling banyak dikonsumsi adalah kelompok serealia. Hasil uji statistik menunjukkan perbedaan yang bermakna untuk keragaman konsumsi bahan makanan antara umur 6-12 tahun dan 13-18 tahun (Tabel 5).

Tabel 5 memperlihatkan bahwa jenis kelamin ternyata tidak menunjukkan hubungan yang bermakna dengan keragaman makanan sarapan $(p>0,05)$. Pada laki-laki, persentase keragaman makanan sarapan sedikit lebih tinggi dengan keragaman 4-7 jenis, sedangkan pada perempuan persentase keragaman lebih tinggi dengan jumlah 1-3 jenis. Hal yang sama juga menunjukkan, hubungan tingkat ekonomi baik, responden dengan ekonomi kurang atau mampu tidak menunjukkan ada hubungan yang bermakna dengan keragaman makanan sarapan $(p<0,05)$.
Namun, wilayah tempat tinggal dan tingkat pendididikan menunjukkan ada hubungan yang bermakna $(p<0,05)$ dengan keragaman konsumsi sarapan. Responden di kota, persentase keragamannya lebih tinggi dengan jumlah keragaman 4-7 jenis, sedangkan di desa, persentase keragamannnya lebih tinggi persentasenya dengan jumlah keragaman 1-3 (kurang beragam) (Tabel 5).

Keragaman makanan yang dikonsumsi antara lain tergantung dari kebiasaan, ketersediaan bahan makanan, ketersediaan waktu, jumlah anggota rumah-tangga dan juga aktivitas yang biasa dilakukan. Kondisi ini akan membawa perbedaan, termasuk berbeda di setiap provinsi. Gambaran banyaknya responden dengan keragaman konsumsi bahan makanan menurut provinsi disajikan pada Tabel 6.

Tabel 6 menunjukkan, provinsi dengan persentase keragaman makanan sarapan 'baik' (4-7 jenis) yang tertinggi adalah Bali $(53,5 \%)$, diikuti DIY $(50,9 \%)$ dan Sumatera Utara $(50,6 \%)$, sedangkan provinsi dengan persentase keragaman makanan sarapan 'kurang' (1-3 jenis) yang tertinggi adalah NTT (87\%), diikuti Papua (82,6\%) dan Maluku $(77,0 \%)$.

Tabel 1

Karakteristik Responden

\begin{tabular}{|c|c|c|c|c|c|}
\hline \multirow{2}{*}{ Karakteristik } & \multicolumn{2}{|c|}{ Umur 6-12 tahun } & \multicolumn{2}{|c|}{ 13-18 tahun } & \multirow{2}{*}{ Total } \\
\hline & $\mathrm{n}$ & $\%$ & $\mathrm{n}$ & $\%$ & \\
\hline \multicolumn{6}{|l|}{ Jenis kelamin } \\
\hline - Laki-laki & 7739 & 52,3 & 6612 & 50,6 & 14351 \\
\hline - Perempuan & 7069 & 47,7 & 6450 & 49,4 & 13519 \\
\hline \multicolumn{6}{|l|}{ Wilayah tempat tinggal } \\
\hline - Perkotaan & 6531 & 44,1 & 5722 & 44,0 & 12253 \\
\hline - Perdesaan & 8277 & 55,9 & 7340 & 56,0 & 15617 \\
\hline \multicolumn{6}{|l|}{ Kuintil kepemilikan/ekonomi } \\
\hline - Kurang & 8543 & 57,7 & 7786 & 59,6 & 16329 \\
\hline - Mampu & 6265 & 42,3 & 5276 & 40,4 & 11541 \\
\hline \multicolumn{6}{|l|}{ Tingkat pendidikan } \\
\hline _ Tidak/belum sekolah & 2645 & 17,9 & 324 & 2,5 & 2969 \\
\hline - Sekolah & 12163 & 82,1 & 12738 & 97,5 & 24901 \\
\hline Jumlah & 14808 & 100,0 & 13062 & 100,0 & 27870 \\
\hline
\end{tabular}


Tabel 2

Sebaran Responden yang Melakukan Sarapan menurut Provinsi

\begin{tabular}{|c|c|c|c|}
\hline Provinsi & $\begin{array}{l}\text { Jumlah } \\
\text { sampel }\end{array}$ & $\begin{array}{c}\text { Jumlah sampel yang } \\
\text { sarapan }\end{array}$ & $\begin{array}{c}\text { Persentase sampel } \\
\text { yang sarapan (\%) }\end{array}$ \\
\hline Aceh & 1586 & 1277 & 80,5 \\
\hline Sumatera Utara & 3017 & 2405 & 79,7 \\
\hline Sumatera Barat & 1356 & 1078 & 79,5 \\
\hline Riau & 930 & 685 & 73,7 \\
\hline Jambi & 774 & 536 & 69,3 \\
\hline Sumatera Selatan & 1307 & 1012 & 77,4 \\
\hline Bengkulu & 684 & 542 & 79,2 \\
\hline Lampung & 1085 & 836 & 77,0 \\
\hline Kep. Bangka Belitung & 443 & 328 & 74,0 \\
\hline Kepulauan Riau & 417 & 331 & 79,4 \\
\hline DKI Jakarta & 379 & 300 & 79,2 \\
\hline Jawa Barat & 2691 & 2190 & 81,4 \\
\hline Jawa Tengah & 2976 & 2330 & 78,3 \\
\hline DI Yogyakarta & 294 & 222 & 75,5 \\
\hline Jawa Timur & 3046 & 2324 & 76,3 \\
\hline Banten & 937 & 763 & 81,4 \\
\hline Bali & 581 & 467 & 80,4 \\
\hline Nusa Tenggara Barat & 817 & 683 & 83,6 \\
\hline Nusa Tenggara Timur & 1537 & 1056 & 68,7 \\
\hline Kalimantan Barat & 997 & 763 & 76,5 \\
\hline Kalimantan Tengah & 675 & 565 & 83,7 \\
\hline Kalimantan Selatan & 887 & 718 & 80,9 \\
\hline Kalimantan Timur & 783 & 582 & 74,3 \\
\hline Sulawesi Utara & 701 & 509 & 72,6 \\
\hline Sulawesi Tengah & 793 & 620 & 78,2 \\
\hline Sulawesi Selatan & 1759 & 1387 & 78,9 \\
\hline Sulawesi Tenggara & 927 & 693 & 74,8 \\
\hline Gorontalo & 381 & 255 & 66,9 \\
\hline Sulawesi Barat & 430 & 317 & 73,7 \\
\hline Maluku & 778 & 560 & 72,0 \\
\hline Maluku Utara & 676 & 533 & 78,9 \\
\hline Papua Barat & 365 & 277 & 75,9 \\
\hline Papua & 941 & 726 & 77,2 \\
\hline Total & 35950 & 27870 & 77,5 \\
\hline
\end{tabular}

Tabel 3

Sebaran Responden menurut Keragaman Bahan Makanan

\begin{tabular}{ccc}
\hline $\begin{array}{l}\text { Jumlah keragamanan } \\
\text { bahan makanan }\end{array}$ & $\mathrm{n}$ & $\%$ \\
\hline 1 & 3892 & 14,0 \\
2 & 5463 & 19,6 \\
3 & 7612 & 27,3 \\
4 & 7543 & 27,1 \\
5 & 2867 & 10,3 \\
6 & 480 & 1,7 \\
7 & 13 & 0 \\
\hline
\end{tabular}


Tabel 4

Sebaran Responden dengan Jumlah Keragaman 1-3 dan Kelompok Bahan Makanan

\begin{tabular}{llc}
\hline Jumlah Keragaman & Kelompok Bahan Makanan & $\%$ \\
\hline 1 Jenis (14\%) & Serealia & 72,0 \\
2 Jenis (20\%) & Serealia, air putih & 49,6 \\
& Serealia, hewani & 18,2 \\
& Seralia dan lainnya & 30,2 \\
3 jenis (27\%) & Serealia, hewani, minyak & 49,6 \\
& Serealia, sayur dan minyak & 14,9 \\
& Serealia, sayur dan air & 10,9 \\
& Serealia dan 2 jenis lainnya & 24,6 \\
\hline
\end{tabular}

Tabel 5

Sebaran Responden menurut Kelompok Keragaman Bahan Makanan

\begin{tabular}{|c|c|c|c|c|c|c|}
\hline \multirow{2}{*}{ Karakteristik } & \multicolumn{2}{|c|}{ Keragaman 1-3 } & \multicolumn{2}{|c|}{ Keragaman 4-7 } & \multirow{2}{*}{ Total } & \multirow{2}{*}{$p$} \\
\hline & $\mathrm{n}$ & $\%$ & $\mathrm{n}$ & $\%$ & & \\
\hline \multicolumn{7}{|l|}{ Kelompok umur } \\
\hline - Umur 6-12 tahun & 9239 & 54,5 & 5569 & 51,1 & 14808 & $<0,05$ \\
\hline - Umur 13-18 tahun & 7728 & 45,5 & 5334 & 48,9 & 13062 & \\
\hline \multicolumn{7}{|l|}{ Jenis kelamin } \\
\hline - Laki-laki & 8678 & 51,1 & 5673 & 52,0 & 14351 & $>0,05$ \\
\hline - Perempuan & 8289 & 48,9 & 5230 & 48,0 & 13519 & \\
\hline \multicolumn{7}{|l|}{ Wilayah tempat tinggal } \\
\hline - Perkotaan & 7372 & 43,4 & 4881 & 44,8 & 12253 & $<0,05$ \\
\hline - Perdesaan & 9595 & 56,6 & 6022 & 55,2 & 15617 & \\
\hline \multicolumn{7}{|l|}{ Kuintil kepemilikan/ekonomi } \\
\hline - Kurang & 10001 & 58,9 & 6328 & 58,0 & 16329 & $>0,05$ \\
\hline - Mampu & 6966 & 41,1 & 4575 & 42,0 & 11541 & \\
\hline \multicolumn{7}{|l|}{ Tingkat pendidikan } \\
\hline _ Tidak/belum sekolah & 1941 & 11,4 & 1028 & 9,4 & 2969 & $<0,05$ \\
\hline - Sekolah & 15026 & 88,6 & 9875 & 90,6 & 24901 & \\
\hline Jumlah & 16967 & 100,0 & 10903 & 100,0 & 27870 & \\
\hline
\end{tabular}

\section{BAHASAN}

Dalam rangka meningkatkan kualitas hidup bangsa, perlu dilakukan peningkatan dalam berbagai hal, salah satunya adalah gizi. Karena gizi berpengaruh terhadap kesehatan, kecerdasan dan produktivitas kerja. ${ }^{1,2,3,4}$ Berdasarkan data Riskesdas 2010, makanan yang dikonsumsi masyarakat Indonesia belum sesuai dengan kebutuhan dan masih ada masyarakat yang kekurangan gizi, tetapi di sisi lain ada yang kelebihan, terutama di daerah perkotaan. Hasil analisis pada anak usia sekolah (6-18 tahun) memperlihatkan, dari sampel SKMI 2014 menunjukkan sebanyak 77 persen yang melakukan sarapan. Hasil penelitian Setyorini (2005) di Depok menemukan proporsi siswa sekolah SD di Depok yang biasa sarapan berada pada kisaran 68,8-80 persen. Hal ini menunjukkan, budaya sarapan sudah tampak, namun perlu ditingkatkan agar semua masyarakat biasa melakukan sarapan. 
Tabel 6

Sebaran Responden dengan Keragaman Konsumsi Bahan Makanan menurut Provinsi

\begin{tabular}{lcc}
\hline Provinsi & Keragaman 1-3 & Keragaman 4-7 \\
\hline Aceh & 51,4 & 48,6 \\
Sumatera Utara & 49,4 & 50,6 \\
Sumatera Barat & 64,1 & 35,9 \\
Riau & 64,8 & 35,2 \\
Jambi & 62,5 & 37,5 \\
Sumatera Selatan & 64,4 & 35,6 \\
Bengkulu & 54,2 & 45,8 \\
Lampung & 56,2 & 43,8 \\
Kep. Bangka Belitung & 69,2 & 30,8 \\
Kepulauan Riau & 68,9 & 31,1 \\
DKI Jakarta & 61,0 & 39,0 \\
Jawa Barat & 56,4 & 43,6 \\
Jawa Tengah & 53,4 & 46,6 \\
DI Yogyakarta & 49,1 & 50,9 \\
Jawa Timur & 53,7 & 46,3 \\
Banten & 65,4 & 34,6 \\
Bali & 46,5 & 53,5 \\
Nusa Tenggara Barat & 59,2 & 40,8 \\
Nusa Tenggara Timur & 87,0 & 13,0 \\
Kalimantan Barat & 65,5 & 34,5 \\
Kalimantan Tengah & 61,1 & 38,9 \\
Kalimantan Selatan & 60,0 & 40,0 \\
Kalimantan Timur & 62,9 & 37,1 \\
Sulawesi Utara & 69,4 & 30,6 \\
Sulawesi Tengah & 67,6 & 32,4 \\
Sulawesi Selatan & 65,6 & 34,4 \\
Sulawesi Tenggara & 73,0 & 27,0 \\
Gorontalo & 60,0 & 40,0 \\
Sulawesi Barat & 63,4 & 36,6 \\
Maluku & 77,0 & 23,0 \\
Maluku Utara & 60,8 & 39,2 \\
Papua Barat & 67,5 & 32,5 \\
Papua & 82,6 & 17,4 \\
\hline Total & 60,9 & 39,1 \\
\hline & &
\end{tabular}

Menurut Pereira et al (2010), ${ }^{14}$ frekuensi sarapan serta kualitas makanan yang dikonsumsi diduga berhubungan dengan kadar gula darah dan nafsu makan pada anak dan orang dewasa, di sisi lain penelitian tentang 'melewatkan' makan pagi dan jenis yang dikonsumsi, dilakukan Priya et al (2012) dengan mengolah data the National Health and Nutrition Examination Survey (NHANES): 19992006, menunjukkan konsumsi sereal siap saji berkaitan dengan peningkatan risiko kardiometabolik. Demikian pula dengan hasil penelitian Smith KJ et al (2010), ${ }^{7}$ yang melakukan penelitian pada anak usia 9-15 tahun di Australia pada tahun 1985. Di sisi lain, menurut Sung Cho et al, ${ }^{16}$ 'melewatkan' sarapan tidak efektif untuk mengatur berat badan, konsumsi sereal siap saji atau roti berhubungan secara bermakna dibandingkan dengan tidak sarapan atau sarapan dengan konsumsi daging atau telur. Oleh karena itu, sarapan tidak hanya ditekankan untuk mengonsumsi makanan atau minuman, tetapi juga dianjurkan jenis makanan yang sebaiknya dikonsumsi. Pada data yang dianalisis, terdapat sampel yang hanya minum teh, tidak disertai 
gula atau makanan lainnya. Hal ini kemungkinan terkait dengan kemampuan ekonomi responden. Dalam analisis ini, lebih dari 50 persen responden berkemampuan ekonomi kurang.

Di Indonesia, menurut Khomsan (2005), ${ }^{17}$ alasan anak tidak biasa sarapan sebelum berangkat sekolah adalah karena tidak tersedia makanan untuk dimakan, bosan, waktu tidak cukup karena harus berangkat pagi. Menurut Sartika (2012), ${ }^{18}$ yang melakukan penelitian di dua SD Kabupaten Bogor menunjukkan, sebagian besar siswa melakukan sarapan di rumah dan yang membawa bekal adalah anak yang rumahnya jauh dari sekolah. Namun, tidak dijelaskan jenis bekal yang biasa dibawa.

Undang-Undang (UU) Kesehatan No. 36/2009 19 tentang Kesehatan serta UU No. $18 / 2012^{20}$ tentang Pangan mengamanatkan pentingnya kesehatan untuk seluruh warga Indonesia dengan mewujudkan gizi seimbang; pesan ke-6 dalam Pedoman Gizi Seimbang, yaitu biasakan makan pagi atau sarapan perlu terus disosialisasikan dan ditingkatkan. Sosialisasi untuk melakukan sarapan saat ini sudah gencar dilakukan di media-media, termasuk media sosial. Pemerintah telah mengadakan Program Pekan Sarapan Nasional yang diperingati setiap tanggal 14-20 Februari. Dengan Pekan Sarapan ini diharapkan ada peningkatan dalam kebiasaan sarapan sesuai dengan kebutuhan dan anjuran. Pada pelaksanaan program Pekan Sarapan ini tidak hanya kebiasaan sarapan, namun juga perlu diperhatikan jumlah serta jenis bahan makanan yang dikonsumsi. Jumlah dan jenis bahan makanan yang dikonsumsi berpengaruh terhadap asupan zat gizi. Komposisi makanan berkadar protein tinggi, menurut Zeng et al $(2011)^{21}$ yang melakukan penelitian pada remaja akhir (18-23 tahun) menunjukkan, kadar gula lebih bertahan dibandingkan dengan komposisi makanan berkadar protein cukup.

Keragaman bahan makanan diperlukan untuk pemenuhan pola makan ber-Gizi Seimbang dengan memperhatikan sumber zatzat gizi makro (zat-zat gizi yang dibutuhkan dalam jumlah besar) seperti karbohidrat, lemak, protein dan air, melainkan juga sumber zat-zat gizi mikro (zat-zat gizi yang dibutuhkan dalam jumlah lebih kecil) seperti vitamin dan mineral, karena tidak ada satu pun jenis makanan yang mengandung semua jenis zat gizi yang dibutuhkan tubuh untuk menjamin pertumbuhan dan mempertahankan kesehatannya. ${ }^{22}$ Makin beragam, semakin tinggi kualitasnya. Kualitas tidak hanya jumlahnya namun juga jenisnya.

Penilaian konsumsi makanan individu sebaiknya tidak hanya melihat dari salah satu komponen saja, tetapi harus menyeluruh, baik kualitas maupun kuantitasnya. Kualitas dan kuantitas konsumsi dikategorikan baik jika keragaman, proporsi dan kecukupan baik/ terpenuhi. Dalam analisis sarapan ini yang dinilai adalah kualitas dari makanan yang dikonsumsi dengan melihat keragaman.

Keragaman makanan pada saat sarapan yang dikonsumsi penduduk dalam analisis ini, dilihat dari wilayah dan jenis kelamin tidak jauh berbeda. Umumnya konsumsi makanan sarapan berasal dari kelompok serealia seperti nasi, mi dan roti yang diolah menjadi hidangan seperti nasi goreng, mi goreng. Kelompok serealia merupakan sumber zat tenaga yang diperlukan untuk beraktivitas sehari-hari. Terigu kurang mengandung asam amino terutama lisin. Oleh karena itu perlu dikonsumsi bersamasama dengan bahan makanan lain yang mengandung asam asam amino lisin yang berasal dari sumber protein hewani seperti daging, telur, sedangkan dari protein nabati, kandungan asam amino yang tinggi berasal dari kacang kedelai.

Hasil analisis menunjukkan, keragaman bahan makanan terdiri dari serealia dan sumber protein hewani. Telur, misalnya, mengandung asam amino lengkap sehingga dapat mengisi kekurangan asam amino yang dikandung serealia. Namun, ditemukan juga kombinasi serealia dengan sayur dan minyak, di mana sayuran hanya mengandung sedikit protein, tetapi mengandung vitamin dan mineral.

Hasil analisis menunjukkan, responden usia 6-18 tahun ada 27 persen yang mengonsumsi sarapan dengan keragaman 3 kelompok bahan, dan persentase tertinggi $(49,6 \%)$ mengonsumsi serealia, lauk hewani dan minyak. Hasil penelitian Hardinsyah dan Aries (2012), ${ }^{5}$ menunjukkan bahan makanan yang banyak dikonsumsi dari kelompok serealia adalah beras yang dikonsumsi dengan kombinasi telor ceplok (kelompok serealia dan minyak), ikan goreng, tempe goreng, tahu goreng. Bila dilihat dari bahan dasarnya, makanan tersebut terdiri dari 2 kelompok bahan 
makanan sehingga menjadi 3 kelompok dengan serealia.

Tidak hanya sumber protein yang perlu diperhatikan. Mengingat jumlah buah dan sayur yang dikonsumsi masih rendah (SDT, 2014), ${ }^{11}$ anjuran untuk menambahkan sayuran pada saat sarapan, termasuk saat mengonsumsi mi, perlu benar-benar ditekankan. Sayuran dan buah merupakan sumber vitamin dan mineral yang berperan sebagai zat pengatur. Makan buah saat sarapan belum menjadi budaya di Indonesia. Terbukti dari hasil analisis, hanya sedikit yang mengonsumsi buah saat sarapan.

Keragaman konsumsi makanan juga diakibatkan kurangnya pengetahuan akan pentingnya makanan sarapan yang beragam. Menurut Sartika (2012), ${ }^{18}$ pengetahuan yang rendah dan sikap ibu dalam merancang menu sarapan agar tidak bosan menjadi masalah yang sering timbul. Menurut Achadi dkk (2010), ${ }^{23}$ pendidikan KIE yang baik, yang dimulai pada anak sekolah, dapat membantu mengubah pengetahuan, sikap dan perilaku anak sekolah. Namun, konsumsi makanan siswa masih sangat tergantung dari praktik para ibu, sementara intervensi tidak ditujukan kepada ibu siswa.

Walaupun hampir semua responden dalam analisis ini berpendidikan, tidak berarti paham akan pentingnya keragaman dalam mengonsumsi makanan sehari-hari. Kurangnya keragaman makanan yang dikonsumsi dapat disebabkan juga karena kemampuan penduduk untuk membeli makanan masih rendah, terutama pada tingkat ekonomi terbawah. Faktor lain adalah ketersediaan waktu ibu atau siapapun yang biasa menyiapkan sarapan di rumah tangga, sebagaimana disampaikan Khomsan (2005) ${ }^{17}$ dan Sartika (2012). ${ }^{18}$ Waktu untuk penyediaan makanan dapat disiasati dengan sudah menyiapkan makanan sarapan pada malam hari.

\section{SIMPULAN DAN SARAN}

\section{Simpulan}

Secara umum sebanyak 77,5 persen anak usia sekolah 6-18 tahun melakukan sarapan, baik berupa makanan lengkap maupun hanya air putih saja. Keragaman makanan sarapan pada anak usia 6-18 tahun menunjukkan, sebanyak 60 persen mengonsumsi hanya 1-3 kelompok atau kurang keragamannya.

\section{Saran}

Pemenuhan gizi seimbang serta kualitas dan kuantitas makanan sarapan pada anak usia sekolah (6-18 tahun) di Indonesia masih rendah. Perlu dilakukan upaya untuk meningkatkan pemahaman mengenai gizi seimbang mulai dari usia dini sampai dewasa melalui edukasi gizi yang melibatkan berbagai sektor terkait, seperti: melalui jalur formal bekerja sama dengan Kementerian Pendidikan dan Kebudayaan dengan memasukkan kurikulum gizi mulai tingkat sekolah dasar sampai dengan menengah atas. Juga dengan Kementerian Dalam Negeri melalui PKK, melalui jalur informal bekerja sama dengan tokoh masyarakat yang mempunyai pengaruh luas seperti ulama atau organisasi masyarakat lainnya.

\section{UCAPAN TERIMA KASIH}

Ucapan terima kasih kami sampaikan kepada Kepala Badan Penelitian dan Pengembangan Kesehatan berserta jajarannya, Tim Survei Konsumsi Makanan Individu (SKMI) 2014, Tim Manajemen Data (Mandat) Badan Litbangkes, yang telah menyiapkan data. Ucapan terima kasih juga kami sampaikan kepada bapak Dr. Abas Basuni Jahari MSc, yang telah memberi arahan dan masukkan dalam proses pengolahan data. Kepada pihakpihak yang terlibat dan tidak dapat disebutkan satu persatu, kami mengucapkan terima kasih atas kerja sama dan bantuannya.

\section{RUJUKAN}

1. Alexander KE, Ventura EE, Spruijt-Metz D, Weigensberg MJ, Goran MI, Davis JN. Association of breakfast skipping with visceral fat and insulin indices in overweight Latino youth. Obesity 2009; 17(8): 1528-33. doi:10.1038/oby.2009.127

2. Amrin $S H$, Indriasari $R$, Najamuddin $U$. Hubungan Kebiasaan Sarapan dan Konsumsi Suplemen dengan Status Hemoglobin pada Remaja Putri di SMAN 10 Makasar. URI: http://repository.unhas.ac.id/handle/123456 789/11304

3. López-Sobaler AM, Ortega RM, Quintas ME, Navia B, Requejo AM. Relationship 
between habitual breakfast and intellectual performance (logical reasoning) in wellnourished schoolchildren of Madrid (Spain). Eur J Clin Nutr. 2003; 57 Suppl 1: S49-53.

4. Rampersaud GC, Pereira MA, Girard BL, Adams J, Metzl JD. Breakfast habits, nutritional status, body weight, and academic performance in children and adolescents. J Am Diet Assoc. 2005; 105(5): 743-60.

5. Hardinsyah, Aries M. Jenis pangan sarapan dan perannya dalam asupan gizi harian anak usia 6-12 tahun di Indonesia, JGP 2012; 7(2): 89-96.

6. Wilson NC, Parnell WR, Wohlers M, Shirley PM. Eating breakfast and its impact on children's daily diet. Nutr Diet. 2006; 63(1): 15-20.

7. Smith KJ, Gall SL, McNaughton SA, Blizzard L, Dwyer T, Venn AJ. Skipping breakfast: longitudinal associations with cardiometabolic risk factors in the Childhood Determinants of Adult Health Study. Am J Clin Nutr. 2010; 92(6): 131625.

8. Sukati. Hubungan kebiasaan makan pagi dengan konsentrasi belajar. Penel Gizi Makan. 1991; 14: 60-73.

9. Permaesih D, Herman S. Faktor-faktor yang mempengaruhi anemia pada remaja. Bul Penel Kes 2005; 33(4): 162-7.

10. Indonesia, Badan Litbangkes Kementerian Kesehatan. Laporan Riset Kesehatan Dasar (Riskesdas) 2010. Jakarta: Badan Litbangkes, 2010.

11. Indonesia, Badan Litbangkes Kementerian Kesehatan. Studi Diet Total, Survey Konsumsi Makanan Individu 2014. Jakarta: Badan Litbangkes, 2014.

12. Indonesia, Badan Litbangkes Kementerian Kesehatan RI. Laporan Riset Kesehatan Dasar (Riskesdas) 2013. Jakarta: Badan Litbangkes, 2013.

13. Setyorini E. Gambaran perilaku sarapan dan hubungannya dengan prestasi belajar siswa kelas 3 dan 4 SD Daar Ei Salam, Bogor. Skripsi. Depok: Fakulas Kesehatan Masyarakat Universitas Indonesia. 2006.

14. Pereira $M A$, Erickson $E$, McKee $P$, Schrankler K, Raatz SK, Lytle LA, et al.
Breakfast frequency and quality may affect glycemia and appetite ini adults and children. J Nutr. 2011; 141(1); 163-8.

15. Deshmukh-Taskar PR, Nicklas TA, O'Neil CE, Keast DR, Radcliffe JD, Cho S. The relationship of breakfast skipping and type of breakfast consumption with nutrient intake and weight status in children and adolescents: the National Health and Nutrition Examination Survey (NHANES): 1999-2006. J Am Diet Assoc. 2010; 110(6): 869-78.

16. Cho S, Dietrich M, Brown CJP, Clark CA, Block $G$. The effect of breakfast type on total daily energy intake and body mass index: results from the Third National Health and Nutrition Examination Survey (NHANES III). J Am Coll Nutr. 2003; 22(4): 296-302.

http://www.tandfonline.com/doi/full/10.1080/ 07315724.2003.10719307?scroll=top\&need Access=true 22 February 2016

17. Khomsan A. Pangan dan Gizi untuk Kesehatan. Bogor: Departemen Gizi Masyarakat Fakultas Ekologi Manusia IPB, 2005.

18. Sartika RAD. Penelitian komunikasi, informasi dan edukasi gizi terhadap perilaku sarapan siswa sekolah dasar. Kesmas. 2012; 7(2): 76-82.

http://jurnalkesmas.ui.ac.id/kesmasphj/articl e/view/66 [5 Oktober 2016]

19. Indonesia, Kementerian Kesehatan. Undang-Undang Kesehatan No. 36 Tahun 2009 tentang Kesehatan.

20. Indonesia, Kementerian Kesehatan. Undang-Undang No. 18 Tahun 2012 tentang Pangan.

21. Zeng YC, Li SM, Xiong GL, Su HM, Wan $\mathrm{JC}$. Influences of protein to energy ratios in breakfast on mood, alertness and attention in the healthy undergraduate students. Health. 2011; 3: 383-93.

22. Indonesia, Ditjen Bina Gizi dan KIA Kementerian Kesehatan. Pedoman Gizi Seimbang 2014. Jakarta: Kementerian Kesehatan RI, 2014.

23. Achadi E, Pujonarti SA, Sudiarti T, Rahmawati, Kusharisupeni, Mardatillah, et 
al. Sekolah dasar pintu masuk perbaikan pengetahuan, sikap dan perilaku gizi seimbang masyarakat. Kesmas. 2010; 5(1): 42-8. 